\title{
The role of the Pompeiu-Hausdorff metric in fixed point theory
}

\author{
VASILE BERINDE and MĂDĂLINA PĂCURAR
}

\section{ABSTRACT.}

The main aim of this note is to highlight the role of the Pompeiu-Hausdorff metric in fixed point theory and, subsidiarily, to touch some issues related to the history of this fundamental concept in modern mathematics. This will allow us to conclude that what is nowadays almost generally called Hausdorff metric (distance) and very seldom Hausdorff-Pompeiu metric (distance) or Pompeiu-Hausdorff metric (distance), should be fairly and correctly named Pompeiu-Hausdorff metric (distance).

Acknowledgements. The research was supported by the Grant PN-II-RU-TE-2011-3-239 of the Romanian Ministry of Education and Research.

\section{REFERENCES}

[1] Banach, S., Sur les opérations dans les ensembles abstraits et leur application aux équations intégrales, Fund. Math., 3 (1922), 133-181

[2] Bercovici, H., Gologan, R. and Timotin, D., Generalizations of some functions defined on L(H) (in Romanian), Stud. Cerc. Mat., 27 (1975), No. 2, 131-156

[3] Berinde, V. and Păcurar, M., Hausdorff metric should be correctly named Pompeiu-Hausdorff metric (submitted)

[4] Birkhoff, G. D. and Kellogg, O. D., Invariant points in function space, Trans. Amer. Math. Soc., 23 (1922), 96-115

[5] Birsan, T. and Tiba, D., One hundred years since the introduction of the set distance by Dimitrie Pompeiu, in System modeling and optimization, 35-39, IFIP Int. Fed. Inf. Process., 199, Springer, New York, 2006

[6] Brouwer, L. E. J., Ueber Abbildungen von Mannigfaltigkeiten, Math. Ann., 71 (1912), 97-115

[7] Calude, C., The Pompeiu distance between closed sets (Romanian), "Gheorghe Ţiţeica and Dimitrie Pompeiu" Symposium on Geometry and Global Analysis (Bucharest, 1973), pp 281-287, Editura Acad. R.S.R., Bucharest, 1976

[8] Covitz, H. and Nadler, S. B., Jr., Multi-valued contraction mappings in generalized metric spaces, Israel J. Math., 8 (1970) 5-11

[9] Deiser, O., Review ZBL 1175.01034, republished in Eur. Math. Soc., Newsletter 88 (2013), 65-68

[10] Dontchev, A. L. and Rockafellar, R. T., Implicit Functions and Solution Mappings: A view from Variational Analysis, Springer, 2009

[11] Fan, Ky., Fixed-point and minimax theorems in locally convex topological linear spaces, Proc. Nat. Acad. Sci. U. S. A., 38 (1952), 121-126

[12] Ganea, T., The distance between closed subsets defined by D. Pompeiu (in Romanian), Acad. Republ. Popul. Romîne, Studii Cerc. Mat., 5 (1954), 25-28

[13] Glicksberg, I. L., A further generalization of the Kakutani fixed theorem, with application to Nash equilibrium points, Proc. Amer. Math. Soc., 3 (1952), 170-174

[14] Hausdorff, F., Grundzüge der Mengenlehre, Viet. Leipzig, 1914

[15] Hausdorff, F., Mengenlehre, Zweite neubearbeitete Auflage, Walter de Gruyter, Berlin, 1927

[16] Hausdorff, F., Mengenlehere, 3 Auflage, Walter de Gruyter, Berlin, 1935

[17] Hausdorff, F., Set Theory, Chelsea Publishing Company, New York, 1957

[18] Istrăţescu, V. I., Fixed Point Theory. An Introduction, Kluwer Academic Publishers, 2001

[19] Kakutani, S., A generalization of Brouwer's fixed point theorem, Duke Math. J., 8 (1941), 457-459

[20] Lorenz, T., Mutational Analysis: A Joint Framework for Cauchy Problems in and Beyond Vector Spaces, Springer, Lecture Notes in Mathematics, Issue 1996, Berlin Heidelberg, 2010

[21] Markin, J. T., A fixed point theorem for set valued mappings, Bull. Amer. Math. Soc., 74 (1968), 639-640

[22] Nadler, Sam B., Jr., Multi-valued contraction mappings, Pacific J. Math, 30 (1969), 475-488

[23] Petruşel, A., Multifunctions and applications, (in Romanian), House of the Book of Science, Cluj-Napoca, 2002

[24] Petruşel, A., Operatorial inclusions, House of the Book of Science, Cluj-Napoca, 2002

[25] Petruşel, A. and Moț, G., Multivalued analysis and mathematical economics, House of the Book of Science, Cluj-Napoca, 2004

[26] Picard, E., Memoire sur la théorie des équations aux déerivées partielles et la méthode des approximations successives, J. Math. Pures Appl., 6 (1890), $145-210$

[27] Poincaré, H., Sur certaines solutions particulières du problème des trois corps, C.R. Acad. Sci. Paris Sér. I, 97 (1883), 251-252

[28] Poincaré, H., Sur le problème des trois corps et les équations de la dynamique, Acta Mathematica, 13 (1890), 1-270

[29] Pompeiu, D., Sur la continuité des fonctions de variables complexes (These), Gauthier-Villars, Paris, 1905, Ann. Fac. Sci.de Toulouse, 7 (1905), 264-315

[30] Pompeiu, D., Oeuvre mathématique. [Opera matematică.], Bucureşti: Editura Academiei Republicii Populare Romîne, XXXI, 533 p. (1959)

[31] Schauder, J., Der Fixpunktsatz in Funktionalrumen, Studia Math., 2 (1930), 171-180

[32] Toader, Gh., Remarques sur la distance entre les ensembles, Bul. Inst. Politeh. Iaşi, Secţ. I, 17(21) (1971), No. 3-4, 103-105

[33] Toader, Gh., A metric of Pompeiu-Hausdorff type for the set of continuous functions, Rev. Anal. Numér. Théorie Approximation, 5 (1976), No. 2 , 213-217 (1977)

[34] Rockafellar, R. T. and Wets, Roger J.-B., Variational analysis, Grundlehren der Mathematischen Wissenschaften [Fundamental Principles of Mathematical Sciences], 317, Springer-Verlag, Berlin, 1998

[35] Rus, I. A., Fixed point theorems for multivalued mappings in complete metric spaces, Math. Japon., 20 (1975), 21-24

[36] Rus, I. A., Principles and Applications of the Fixed Point Theory, (in Romanian), Editura Dacia, Cluj-Napoca, 1979

[37] Rus, I. A., Basic problems of the metric fixed point theory revisited (II), Stud. Univ. Babeş-Bolyai, 36 (1991), 81-99

[38] Rus, I. A. Generalized Contractions and Applications, Cluj University Press, Cluj-Napoca, 2001

* Dedicated to Professor Emeritus Constantin Corduneanu on the occasion of his 85th birthday

Received: 15.06.2013; In revised form: 22.08.2013; Accepted: 12.09.2013.

2010 Mathematics Subject Classification. 47H10, $47 \mathrm{H} 04$.

Key words and phrases. Pompeiu-Haussdorff distance, fixed point theory 
[39] Rus, I. A., Petruşel, A. and Petruşel, G., Fixed point theory: 1950-2000. Romanian contributions, House of the Book of Science, Cluj-Napoca, 2002

[40] Rus, I. A., Petruşel, A. and Sîntămărian, A., Data dependence of the fixed point set of some multivalued weakly Picard operators, Nonlinear Analysis, 52 (2003), 1947-1959

[41] Rus, I. A., Petruşel, A. and Petruşel, G., Fixed Point Theory. Cluj University Press, Cluj-Napoca, 2008

[42] Sergescu, P., D. Pompeiu (1873-1954) (in French), Enseign. Math., 40 (1955), 70-71

DePartMent of MATHEMATICS AND COMPUTER SCIENCE

NORTH UNIVERSITY OF BAIA MARE

Victoriei 76, 430072 BAIA MARE, ROMANIA

E-mail address: vberinde@ubm.ro; vasile_berinde@yahoo.com

Department of Statistics, ANALysis and Mathematics

FACULTY OF ECONOMICS AND BUSSINESS ADMINISTRATION

BABEŞ-BOLYAI UNIVERSITY OF CLUJ-NAPOCA

56-60 T. Mihali ST., 400591 Cluj-NAPOCA, Romania

E-mail address: madal ina.pacurareecon.ubbcluj.ro 